\title{
Features of Breast Cancer in Diabetes Mellitus
}

\author{
Cherenkov VG*, Pacewicz KG and Frumkin BB \\ Regional Clinical Oncological Dispensary, Veliky Novgorod, Russia \\ *Corresponding author: Cherenkov VG, Regional Clinical Oncological Dispensary, Veliky Novgorod, Russia
}

\begin{tabular}{|c|c|}
\hline ARTICLE INFO & ABSTRACT \\
\hline Received: 綇 January 24, 2021 & $\begin{array}{l}\text { Citation: Cherenkov VG, Pacewicz KG, Frumkin BB. Features of Breast Cancer in Diabetes } \\
\text { Mellitus. Biomed J Sci \& Tech Res 34(1)-2021. BJSTR. MS.ID.005499. }\end{array}$ \\
\hline
\end{tabular}

\section{Introduction}

In our country, on a par with developed countries (more than 60 thousand women suffer from diabetes and its frequency increases every year). The scientific conference in St. Gallen (2011) made a significant contribution to the classification of breast cancer heterogeneity and identified four main subtypes: Luminal A, Luminal B, with HER2 overexpression and triplet in an average ratio of 50: 13: 10: 17. The risk of developing breast cancer is between 20 and $30 \%$ for women with diabetes in their 50s. Chemotherapy for breast cancer patients with metabolic disorders (DM) is a complex task. At the same time, many authors have shown that there are more diabetics who have recovered from cancer than those who have never suffered from it. What is the reason for this situation?

\section{Aim}

To study the ratio of breast cancer subtypes in patients with DM and their 5 - year survival rate.

\section{Material and Results}

Studies of breast cancer subtypes were conducted in 196 patients (143 without DM and 53 with DM 2 - 29.04\%) as they were admitted to the case-control mammology department. In addition, as a control group, the analysi s of breast cancer subtypes was carried out in 325 patients with subtypes taken into account in 2017). At the same time, 283 patients were registered with stage III breast cancer, including the percentage of stage I-II patients with DM was $-73 \%$, and $67 \%$ without diabetes mellitus [1].

Luminal subtype A was diagnosed somewhat more frequently in breast cancer patients with DM (62,3\% vs. 57.9\%) and luminal B (18.8\% vs. $15.3 \%)$ compared to these subtypes without DM, the differences were not statistically high $(p=0.059)$. The triplet

subtype with DM (15.09\%) was less than 4\% without DM. The herceptin subtype in patients with DM was found to be almost 2 times less (3.8\% vs. $6.2 \%)$ than without DM ( $p<0.0038)$ [2].

At the beginning of 2020, the observed 5-year survival rate of breast cancer was 2,360 women [3]. Retrospective analysis of outpatient records of 190 patients with breast cancer who were registered at the dispensary for 5 or more years, who applied for control in the last 6 months) showed that 54 women had diabetes before surgery (28.4\%), after treatment, in 27 of them the sugar level did not exceed the normal level, limited only by diet. The 5 -year survival rate of breast cancer women with DM was $28.4 \%$ (the ratio of 5-year survival in the analyzed group of patients with DM and without was 1: 2.4).

\section{Discussion}

It is known that a malignant tumor for its growth and development, regardless of localization, arising under the influence of a number of factors, requires energy resources. First of all, it uses glucose, forming angioneogenesis, as a kind of "trap". That is why DM2 can be detected 2-3 years before the tumor itself is detected. Insulin is a tissue growth factor, acting on the cells of the MJ and forcing them to produce a hormone-insulin-like growth factor 1 (IGF-1), having mitogenic properties, while suppressing apoptosis.

\section{Conclusions}

DM2 serves as an indication for opportunistic mammographic screening. In patients with DM, there is a predominance in the frequency of luminal subtypes occurring more favorably. An earlier diagnosis contributes to an increase in the 5-year survival rate of patients with DM. An important aspect of this problem is the prevention of diabetes and metabolic rehabilitation. 


\section{References}

1. Berstein LM (2013) Endocrinology of breast cancer as a heterogeneous disease: a decade after the millennium. Questions of Oncology 59(3): 292-298.

\section{ISSN: 2574-1241}

DOI: 10.26717/BJSTR.2021.34.005499

Cherenkov VG. Biomed J Sci \& Tech Res

(C) This work is licensed under Creative Commons Attribution 4.0 License

Submission Link: https://biomedres.us/submit-manuscript.php
2. Semiglazov VF, Semiglazov VV, AE Kletsel (2016) Non-invasive and invasive breast tumors. Diabetes mellitus and cancer 20: 1346-1350.

3. (2020) The state of cancer care for the population of Russia in 2019 Moscow. In: Mnioi PA Herzen - branch FGBU "SMRC radiology" of Ministry of health of Russia pp. 239.

$\begin{array}{ll}\text { BIOMEDICAL } & \text { Assets of Publishing with us } \\ \text { RESEARCHES } & \text { - Global archiving of articles } \\ \text { - Immediate, unrestricted online access } & \text { - Rigorous Peer Review Process } \\ & \text { - Authors Retain Copyrights } \\ \end{array}$

